\title{
A WORM THAT CARES.
}

BY XIMENA MCGLASHAN, TRUCKEE, CALIFORNIA.

Does the worm have care or thought for the adult it is to produce? Many writers assert that there are no signs of sentiment in any of the stages of moth or butterfly existence. They say the mother fly lays her eggs because of natural law, the eggs hatch because they must, the larva: simply live to eat, and the chrysalis, however wonderful, is only a part of the process. That is all very interesting, but the mother never sees nor cares for her progeny, nor does the offspring care for anything but itself. If one were to cross pens in a friendly tilt with these writers, the best illustrations of loving care would doubtless be sought in the pains and trouble which the mother fly manifests in depositing her eggs, or in the solicitude of the larva for the protection of its pupa.

In my home at Truckec, California, there is a species of Cossus, which Barnes and McDunnough say is "probably Cossus angrezi Bailey," which lays its eggs under the bark and in the wood of the cotton-wood tree in August. The female will oviposit if confined in a paper bag, and lays more than a hundred eggs; but, if allowed to have her own way, she hides each egg in the wood or bark of the tree. The larva burrow into the interior of the trunk, and up to the time when they wish to pupate they are entirely hidden from view. They pupate in the bottom of their burrow, and if they only plan for themselves there would seem to be no reason why they should delay the transformation when the time arrives. As a matter of fact, however, they seem to know that the adult must have access to the open air which they themselves have never breathed. Just before pupation they carry their burrow to the surface and smooth the jagged ends of the bark and wood of the opening so that nothing will retard the egress of the moth. They do one thing more which shows a high order of instinct, if it be not reason. The diameter of the opening, just at the surface, is made a trifle less than that of the burrow itself. A little thin ledge projects inward all around the edges of the hole. When the adult is ready to cmerge, with the large pupa-case around its body, it arrives at the projecting ledge on the inner side of the opening, and the case itself is a trifle too large to slip through. It is held fast by the ledge whilc

October, 1913 
the adult pulls itself out. When the moth has escaped, bits of the end of the pupa case project outside the burrow, and the empty case may be forcibly extracted before it dries. If this Cossus larva pupated in the earth at the foot of the tree there would be a good reason why it should have carried the burrow to the surface. As it does not pupate outside the tree, and as it remains in the open air only long enough to shape and smooth the opening, may we not conclude that here is a worm which cares for its adult?

\section{A REMARKABLE NEW PLATYGASTERID GENUS FROM ALSTRALIA.}

BY ALAN P. DODD, NELSON, N. Q. AUSTRALIA

Platygastoides nov. gen.

Female (?).-Head transverse, as wide as the thorax; ocelli far apart, the lateral ones touching the eye margins. Antenna 10jointed; scape extraordinarily dilated, scarcely longer than wide, half as wide as the head; when in the normal position the rest of the antenna lies back along the scape; pedicel slender, twice as forng as wide; 1st funicle joint as long as the pedicel and natrower; 2nd as long as wide; 3rd and 4th wider than long; club 4-jointed; 1 st joint very short, transverse; club joints $2-4$ large, wide.

Thorax short, scarcely longer than wide; pronotum scarcely risible from above; mesonotum wide, with the parapsidal furrows present, wide apart; outside the parapsidal furrows are two parallel groove lines; scutellum semicircular, with a median groove line; metanotum with two deep sulci, separated by a median carina; lateral edges of the sulci carinate.

Fore wings rather short, broad, without veins. Abdomen sessile, as wide as the thorax, and longer than the head and thorax unitod; 2nd segment equal to one-half the abdominal length.

Legs rather short; tarsi j-jointed.

Type.--The following species:

Platygastoides mirabilis sp. nov.

Female (?),-Length, $1.50 \mathrm{~mm}$. Black; legs, except coxa, reddish yellow; antennce reddish yellow, the scape and club suf-

October, 10!3 